\title{
NUMERICAL AND EXPERIMENTAL ANALYSIS OF STRESS OF A SEMI-ELLIPTICAL SPRING
}

\author{
Mariusz Stańco $^{1}$, Artur Iluk ${ }^{1}$, Paulina Dzialak ${ }^{1}$ \\ 1 Wroclaw University of Science and Technology, Department of Mechanical Engineering, \\ Łukasiewicza 7/9, 50-371 Wrocław, Poland. E- \\ mail: mariusz.stanco@pwr.edu.pl, artur.iluk@pwr.edu.pl, paulina.dzialak@pwr.edu.pl
}

\section{Introduction}

There are two types of the suspension systems offered for the heavy goods vehicles: pneumatic, based on the airbags and the standard ones using the leaf springs. The suspension is selected for each vehicle individually. Decisive influence on the type of the system has a vehicle's purpose. In the military vehicles, suspension systems based on the leaf springs prevail significantly.

\section{Object specification}

A research object, subjected to the numerical and experimental analysis, was the leaf spring. This element is utilized in heavy-duty vehicles, operated in very difficult site conditions. It is used as a spring element in the frontal axis of three and four axle vehicles. A general view of the analysed object is shown in figure 1 . It is comprised of the nine leaves with a variable length. The value of a nominal stiffness of the examined spring was defined and it was around 330N/mm.

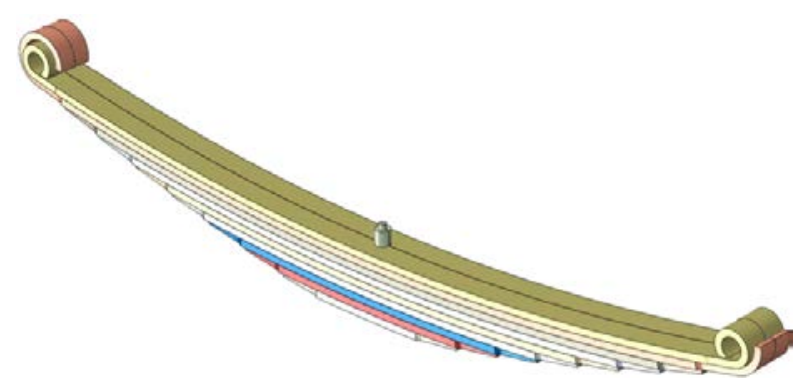

Fig. 1. General view of a leaf spring.

\section{Experimental testing}

In order to determine the number of cycles, which the analysed spring is able to resist, a specific test stand was built. It enabled to conduct a fatigue test of a complete object in a controlled way (fig. 2).

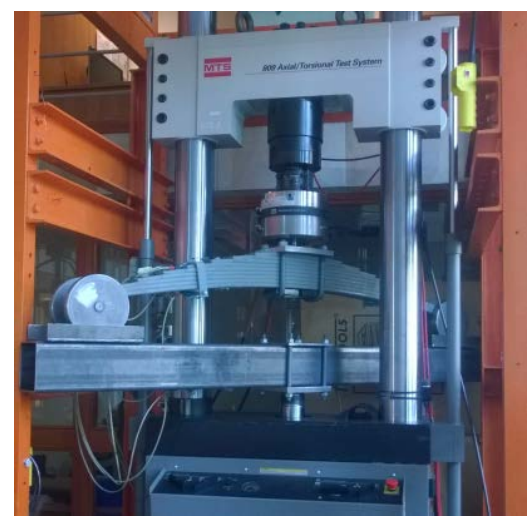

Fig. 2. Testing rig.

The type of a cover of the spring strongly influence the stiffness and the operation of the element. The authors managed to recreate the mounting of the leaf spring on the vehicle. In the middle part of the object the deflection was restricted by the clamp. The endings of the element were placed on the rollers. It enabled unlimited length change during the spring deflection.

The examination was conducted continuously, by the control of the displacement. The aim of the research was to determine the number of cycles with the maximal bend deflection, which the spring can resist.

The experiment was ended after 76 thousands of cycles, when the cracks on the both sides of the mounting between the spring and the frontal axis appeared.

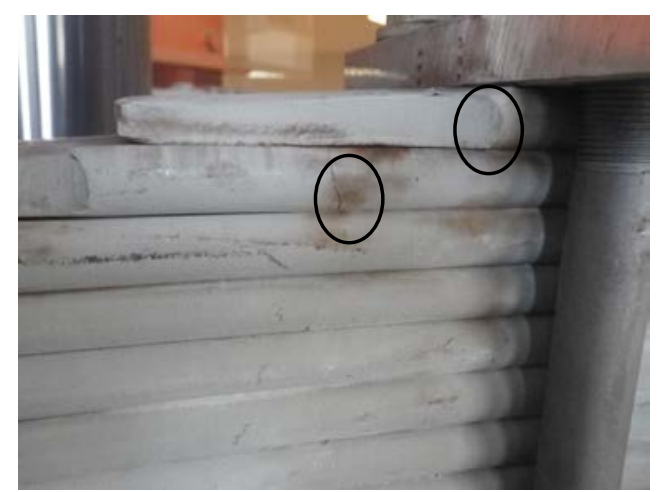

Fig. 3. Cracks on the object examined on a test stand. 


\section{Numerical model}

The experimental study [1-3] enable only spot measurement of the stresses and displacements. Complete overview of the results is possible through the numerical analysis.

A computational model [4] of the examined spring was created (fig. 4). It reflected all the necessary geometric features of the object. Due to the existing symmetry of the geometry and of the loading, the calculation was made for only a half of the model. Boundary conditions, enabling this type of the analysis were used. The loads acting between the leaves of the spring was considered by applying a proper contact connection.

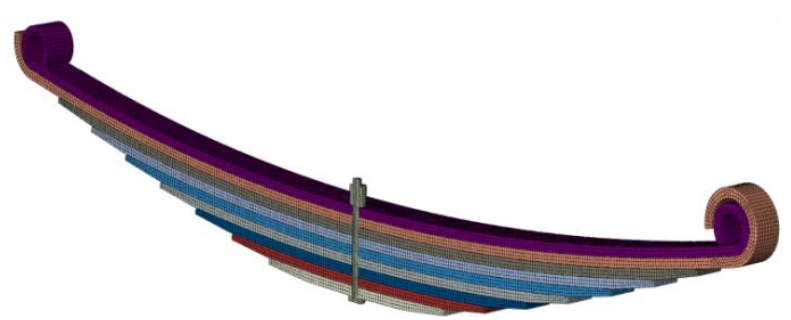

Fig. 4. Discrete model of the analysed leaf spring.

In order to verify a numerical model, comparison of the computational and experimental examination was made. The authors compared received strains, displacements and the reaction forces. There was a broad convergence of the obtained results (fig. 5).

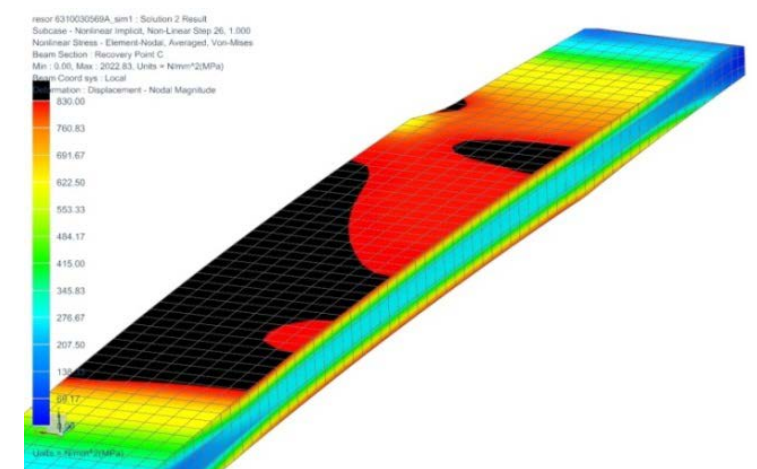

Fig. 5. Distribution of stress contour lines reduced based on H-M-H hypothesis in leaf no. 7.

After adjustment of the numerical model, the influence of the mounted rubber bumpers on the stress values was examined. Figure 6 presents the analysed object in the initial position and in the moment of maximal deflection of the rubber rolls.

An obtained from the numerical simulation stress contour lines confirmed, that the cracks on the object appeared in the spots where the maximal stresses occurred.

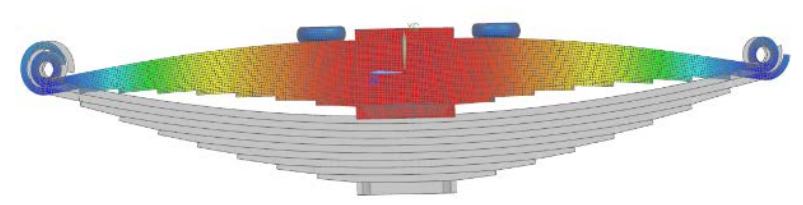

Fig.. 6. Displacement contour lines for the maximal deflection of the rubber bumpers.

\section{Summary}

The experiment and the numerical analysis of the parabolic spring was conducted in order to determine the causes of the crack in the spring structure while operating in the difficult site conditions. On that basis the authors stated that:

- The experimental test established that durability of the analysed spring, while operating on the entire work range, is limited to tens of thousands cycles. It is insufficient number for the vehicle designed for working in the difficult and challenging terrain conditions.

- Numerical simulations confirmed that the cracks appeared in the spots where stress obtained maximal values. It indicates the spring overload, not the material defects.

- The durability of the analysed spring will not allow to exploit the system in the vehicle, which suspension is subjected to the large number of cycles with a high amplitude. Research identified the need of the spring structure modification and/or adjustment of the operating range.

\section{References}

[1] Kosobudzki M., Kowalczyk M., Stańco M.: Aktywizacja obciążeń dynamicznych działających na pojazd generowanych przez układ jezdny, Transport Przemysłowy, 2007, Vol. 4, pp. 82-85.

[2] Kosobudzki M, Stańco M. The experimental identification of torsional angle on a loadcarrying truck frame during static and dynamic tests. Maintenance and Reliability 2016; 18 (2). pp. 285-290.

[3] Stańco M., Kosobudzki M.: The loads identification acting on the $4 \times 4$ truck. Materials Today 2016, Vol. 3(4), pp. 167-170.

[4] Rusiński E.: Zasady Projektowania Konstrukcji Nośnych Pojazdów samochodowych. Oficyna Wydawnicza Politechniki Wrocławskiej. Wrocław 2002. 